\title{
Patterns of Proteolytic Enzyme Activities in Different Tissues of Germinating Corn (Zea mays L.)
}

\author{
U. Feller*, Tai-Sen T. Soong, and R.H. Hageman \\ Department of Agronomy, University of Illinois, Urbana, IL 61801, USA
}

\begin{abstract}
Profiles of $\mathrm{pH}$ dependence and activities of five proteolytic enzymes, amino- and carboxypeptidase and endopeptidases active at $\mathrm{pH} \mathrm{3.8,5.4}$ and 7.5 , with casein as substrate, were determined in crude extracts from the various organs of corn seedlings during germination and early development $\left(30^{\circ} \mathrm{C}\right.$, dark, $8 \mathrm{~d}$ ). With respect to the endopeptidases, caseolytic activities at $\mathrm{pH} 3.8,5.4$ and 7.5 in extracts from endosperm increased concurrently with loss of endosperm $\mathrm{N}$ during germination; however, the relative amounts of the $\mathrm{pH} 7.5$ activity were very small. In scutellum extracts, caseolytic activities at both $\mathrm{pH} 5.4$ and 7.5 increased during the initial stages of development but only the increase at pH 5.4 was concurrent with loss of scutellar $N$. In shoot extracts, caseolytic activities at pH 5.4 and 7.5 were very low and remained relatively constant. There was a progressive increase in shoot $\mathrm{N}$ with time. In root extracts, caseolytic activities at $\mathrm{pH} 5.4$ and 7.5 were higher (3-fold) than in shoot extracts. The activity at $\mathrm{pH} 5.4$ remained constant while the activity at $\mathrm{pH} 7.5$ increased during germination. The rate of accumulation of $\mathrm{N}$ by the root was low after day 5 . The pattern and ratio but not the amounts of the pH 5.4 and 7.5 caseolytic activities of the root were similar to those observed in senescing leaves of field-grown corn. Addition of mercaptoethanol increased (several-fold) the caseolytic activities at $\mathrm{pH} 3.8$ and 5.4, especially the latter, but not the $\mathrm{pH} 7.5$ activity in endosperm extracts and increased the $\mathrm{pH} 5.4$ activity in extracts from scutellum $(30 \%)$ and roots $(30 \%)$ while the effect in shoot extracts was negligible. Carboxypeptidase activity was relatively low in young tissue (root tip, 3-d-old shoots) and increased with development of the various organs except the roots (whole) where the activity remained relatively constant. The increases in carboxypeptidase activities were concurrent
\end{abstract}

* Present address: Pflanzenphysiologisches Institut, Universität Bern, Altenbergrain 21, CH-3013 Bern, Switzerland

Abbreviations: AP, aminopeptidase; $\mathrm{CA}$, caseolytic activity; $\mathrm{CP}$, carboxypeptidase; $\mathrm{ME}$, mereaptoethanol with decreases in $\mathrm{N}$ from endosperm and scutellum; this result indicates that this enzyme in these tissues may be involved (cooperatively with endopeptidases) in the mobilization of reserve protein.

Of all the enzymes tested, only carboxypeptidase activity was markedly (in excess of 50\%) inhibited by phenylmethylsulfonylfluoride. Only aminopeptidase activity was found in appreciable amounts in endosperm and scutellum of dry kernels. Aminopeptidase activity was highest in organs with high metabolic activity (scutella, shoot, root tips) and decreased in plant parts undergoing rapid loss of nitrogen (endosperm, senescing leaves).

Key words: Aminopeptidases - Carboxypeptidases - Endopeptidases - Germination (seeds) Proteases - Seedling development - Zea.

\section{Introduction}

Proteases have been classified as endopeptidases (with acidic, sulfhydryl-, serine- and metal-dependent subclasses) and amino- and carboxypeptidases (see review by Ryan, 1973). In general the endopeptidases from germinating seeds - as far as tested - have been found to be sulfhydryl-dependent, with optimum activity under acidic conditions (Basha and Beevers, 1975; Chrispeels and Boulter, 1975; Harvey and Oaks, 1974a, b; Prisco et al., 1975). With barley aleurone layers, Sundblom and Mikola (1972) found measurable amounts of a neutral, metal- but not sulfhydryl-dependent enzyme although the bulk of the endopeptidase activity was acidic and sulfhydryl-dependent. Harvey and Oaks $(1974 \mathrm{a}, \mathrm{b})$ reported that a pH 3.8 endopeptidase plays a prominent role in the mobilization of endosperm protein during germination of corn. The enzyme hydrolyzed hemoglobin, casein and zein. In extracts from germinating corn, Fujimaki et al. (1977) found two endopeptidases (pH optima 3.0 and 6.0 with casein) and the same extracts also 
degraded zein (pH 4.5). Abe et al. (1977) purified the $\mathrm{pH} 3.2$ endopeptidase from the endosperm of germinating corn to homogeneity. Although evidence was also found for the existence of the second enzyme, it was not purified or characterized. Jacobson and Varner (1967) showed de-novo synthesis of an acidic (pH 4.5), sulfhydryl-dependent endopeptidase by isolated barley aleurone layers. From these studies, it has been concluded that the acidic endopeptidases play a major role in the mobilization of the seed protein.

Racusen and Foote (1970) purified an endopeptidase ( $\mathrm{pH}$ optimum 9-10) from bean leaves. This enzyme activity increased with leaf development and the enzyme hydrolyzed denatured bean-leaf protein. In corn leaves, Feller et al. (1977) found two endopeptidases with $\mathrm{pH}$ optima of 5.4 and 7.5 (with casein as substrate). Both activities, especially that of the pH-7.5 enzyme, increased slowly with leaf development and rapidly with senescence (loss of leaf protein). These studies indicated but did not prove that the $\mathrm{pH} 7.5$ endopeptidase also played a major role in the mobilization of leaf protein during grain development.

Although AP activity ( $\mathrm{pH}$ 6.5-6.7) has been found in substantial amount in germinating caryopses of barley (Sopanen and Mikola, 1974) and mung-bean seeds (Chrispeels and Boulter, 1975), no relationship was apparent between the activity of this enzyme and seed-protein mobilization. $\mathrm{CP}$ has been isolated from germinating barley grains (Visuri et al., 1969) and found in germinating mung beans (Chrispeels and Boulter, 1975). Although the activity increased (50\%) during the germination of mung beans, the enzyme was not ascribed a major role in the mobilization of the seed protein. Subsequent work indicated however that it may play a role, although only a secondary one, in protein mobilization (Baumgartner and Chrispeels, 1977).

Little work has been reported on the distribution and relative levels of activity of exo- and endopeptidases in various plant parts during germination. In germinating barley, Mikola and Kolehmainen (1972) identified eight peptidases ( 3 amino, 3 carboxy, and 2 specific). The developing shoot, mesocotyl and rootlets were characterized by having high levels of AP and relatively low levels of the other peptidases. The aleurone layer and the scutellum had high levels of activity of all classes of peptidases while the endosperm was unique in having only the CP's. Because no evidence was found for the existence of preformed for the CP's found in the endosperm, the authors suggested that the enzymes were synthesized in the scutellum and secreted into the endosperm. They also proposed that the role of the peptidases in the scutellum was to hydrolyze peptides derived by hydrolysis of the storage protein. In a similar vein, Higgins and Payne (1977) described an active uptake of dipeptides from the endosperm by barley embryos. Burger and Siegelman (1966) found that extracts from all tissues, with the exception of the aleurone layer, of germinating barley were inactive with $\alpha$-N-benzoyl-DL-arginine- $p$-nitroanilide as substrate. Melville and Scandalios (1972) found detectable levels of a $\mathrm{pH}-7.5$ endopeptidase $(\alpha-\mathrm{N}$-benzoyl-DL-arginine- $p$-nitroanilide as substrate) in all parts (scutellum, root, embryonic axis, leaf, pericarp) of corn seedlings. In all organs and tissues, activity was highest in the earliest stages of seedling development and decreased in a linear manner over the 18-d experimental period. The highest activity was found in the scutellar tissue.

The objectives of the work to be reported in this paper were (1) to determine the relative activities of AP's and CP's, and endopeptidases in endosperm, scutellum, root and shoot of corn during the first $8 \mathrm{~d}$ of development, counted from the beginning of germination (soaking of the kernels), and (2) to attempt relating the activity pattern of the enzymes to the hydrolysis and mobilization of protein nitrogen in the respective organs during germination and early seedling growth.

\section{Material and Methods}

\section{Plant Material}

Kernels (caryopses) of hybrid corn (Zea mays L.), genotype A632 $\times$ Oh43 (Illinois Foundation Seeds, Inc., Champaign, Ill., USA) were used except where otherwise noted. The kernels were washed for $1 \mathrm{~h}$ in running tap water to remove the fungicide with which they had been routinely treated, and then were planted (embryo down, 100 kernels/dish) on paper towels lining the bottom of a glass tray $(22 \mathrm{~cm} \times 34 \mathrm{~cm} \times 4 \mathrm{~cm})$. The towels were saturated with $2.5 \mathrm{mM} \mathrm{CaSO}_{4}$. After sealing the dish with clear polyethylene wrap, 10 small slits were cut in the wrap for aeration. The kernels were germinated in the dark at $30^{\circ} \mathrm{C}$ and supplied with $\mathrm{CaSO}_{4}$ solution as needed. At each harvest, triplicate samples each of 10 seedlings (or more where needed) were randomly selected from 3 trays of seedlings. After sampling, the seedlings were immediately separated into roots, shoots, scutellum, and endosperm (the latter including pericarp and aleurone layer). One replicate of each sample was used for determining fresh and dry weight and $\mathrm{N}$ content, while the other two replicates were weighed and then stored at $-20^{\circ} \mathrm{C}$ for subsequent enzyme assays. Zero-germination-time activity was determined in endosperm and scutella excised from dry kernels, after the fungicide was removed by buffing with paper.

\section{Enzyme Extraction}

The frozen samples were ground in $10 \mathrm{ml}$ extraction medium with a Virtis 45 homogenizer (Virtis Research Equipment, Gardiner, N.Y., USA) for $1 \mathrm{~min}$ at low and $1 \mathrm{~min}$ at medium speed. The extraction medium contained $1 \%(\mathrm{w} / \mathrm{v})$ in soluble polyvinylpyrolidone and $10 \mathrm{mM} \mathrm{ME}$ in $0.05 \mathrm{M}$ acetate buffer adjusted to $\mathrm{pH} 5.4$ with $\mathrm{KOH}$. The homogenate was filtered through four layers of 
cheesecloth and centrifuged at $3,000 \times g$ for $10 \mathrm{~min}$. The supernatant was used for the enzyme assays either immediately or after storage overnight at $2^{\circ} \mathrm{C}$.

\section{Enzyme Measurements}

The clarified supernatants were desalted by filtration through a Sephadex G-25 column and assayed as described in Feller et al. (1977). In some instances, desalting was done by dialysis. The AP and CP activities were determined as the hydrolysis rate of L-leucine- $p$-nitroanlide and $N$-carbobenzoxyl-L-phenylalanine- $\mathrm{L}$ alanine, respectively. The endopeptidase activities were measured by the rate of production of trichloroacetic-acid-soluble amino groups (ninhydrin) from casein. The $\mathrm{pH} 3.8$ and $\mathrm{pH} 5.4$ sulfhydryldependent endopeptidase activities were assayed at $37^{\circ} \mathrm{C}$ in $0.05 \mathrm{M}$ acetate that contained $10 \mathrm{mM} \mathrm{ME}$; the $\mathrm{pH} 7.5$ activity was assayed in a $0.05 \mathrm{M}$ Tris- $\mathrm{HCl}$ buffer at $45^{\circ} \mathrm{C}$, unless otherwise noted.

\section{Nitrogen Content}

The dried plant parts were ground and duplicate 10-mg samples digested by micro-Kjeldahl procedure and assayed (Nessler's reagent) for ammonia.

\section{Results}

\section{pH Profiles}

In crude extracts of endosperms, scutella, shoots and roots of 4-d-old corn seedlings, the $\mathrm{pH}$ optimum ranged from 6.7 to 7.15 for AP activity, and from

Table 1. Aminopeptidase and carboxypeptidase activities extracted from endosperm, scutellum, shoot and roots of corn seedlings as a function of the $\mathrm{pH}$ of the assay medium.

The amino- and carboxypeptidase activities were from tissue of 3- and 6-d-old seedlings, respectively. The buffers used were $0.1 \mathrm{M}$ phosphate (below pH 3.5 and $\mathrm{pH} 6-8), 0.1 \mathrm{M}$ acetate $(\mathrm{pH} 3.5-6)$ and $0.1 \mathrm{M}$ borate (above $\mathrm{pH} 8$ ).

Activities in relative units

\begin{tabular}{lllll}
\hline Assay pH & Endosperm & Scutellum & Shoot & Root \\
\hline \multicolumn{2}{l}{ Aminopeptidase } & & & \\
4.76 & 0.01 & 0.00 & 0.03 & 0.00 \\
5.20 & 0.04 & 0.05 & 0.10 & 0.04 \\
5.74 & 0.12 & 0.13 & 0.15 & 0.07 \\
6.70 & 0.32 & 0.96 & 0.64 & 0.28 \\
7.15 & 0.41 & 0.83 & 0.75 & 0.29 \\
7.50 & 0.30 & 0.55 & 0.62 & 0.26 \\
8.14 & 0.22 & 0.37 & 0.51 & 0.18 \\
8.90 & 0.05 & 0.22 & 0.22 & 0.04 \\
Carboxypeptidase & & & \\
2.30 & 0.14 & 0.18 & 0.17 & 0.10 \\
3.10 & 0.35 & 0.58 & 0.15 & 0.14 \\
4.05 & 0.62 & 1.11 & 0.18 & 0.23 \\
4.92 & 0.63 & 1.14 & 0.12 & 0.19 \\
5.35 & 0.64 & 1.04 & 0.13 & 0.20 \\
6.35 & 0.37 & 0.44 & 0.07 & 0.21 \\
7.50 & 0.14 & 0.15 & 0.10 & 0.16 \\
\hline
\end{tabular}

4.05 to 5.35 for CP activity (Table 1 ). These values are similar to those obtained with crude extracts of corn leaves (Feller et al., 1977), and AP and CP activity were routinely assayed at $\mathrm{pH} 7.0$ and 5.0 , respectively.

The $\mathrm{pH}$ profiles of endopeptidase (caseolytic) activities of crude extracts from various organs of corn seedlings, assayed with and without $\mathrm{ME}$, are shown in Figure 1. In endosperm (3n) tissue, the presence of at least two endopeptidases (pH 4.0 and 5.5) was indicated. There was little or no activity at neutral or alkaline $\mathrm{pH}$ 's. In vegetative $(2 \mathrm{n})$ organs (scutellum, root, shoot) highest activity was observed at $\mathrm{pH} 5.5$, especially with scutella and roots. In these three organs there was little evidence for the presence of a pH-3.8 endopeptidase; however, appreciable activity was found at neutral and alkaline $\mathrm{pH}$ 's. Because crude extracts were used, a portion of the activity at $\mathrm{pH} 4-5$ may be attributable to cooperative CP activity (Baumgartner and Chrispeels, 1977). It is not known whether or not AP contributes to the activity of crude extracts when assays are made at $\mathrm{pH} 6.5$ to 7.5. Based on these results and because we wanted to compare these data with the results of a previous study (Feller et al., 1977), the endopeptidase activity of the vegetative
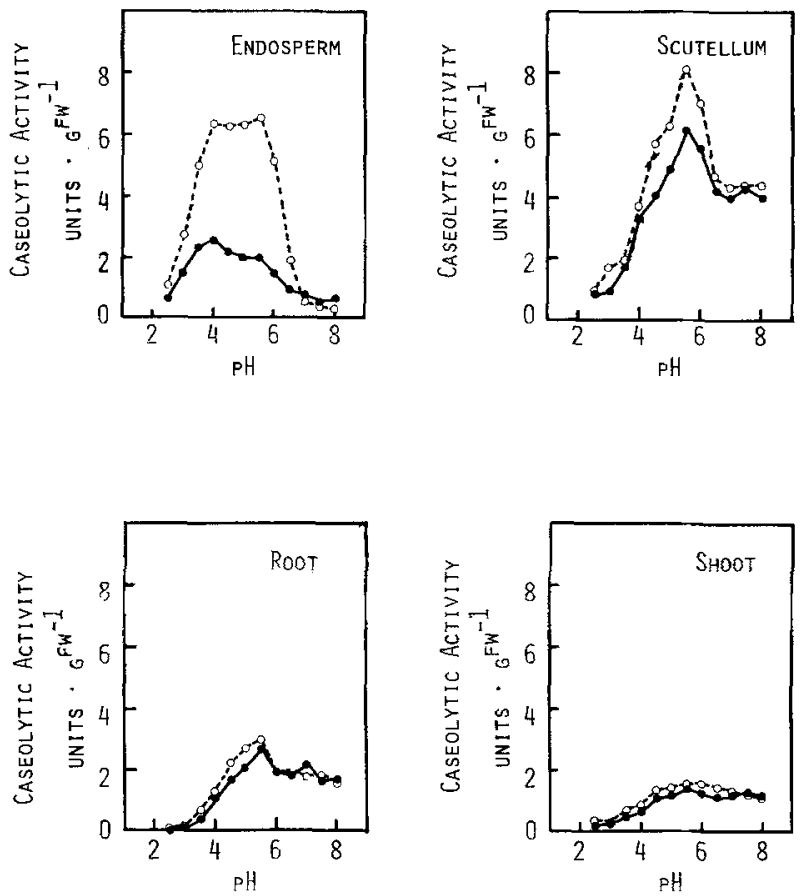

Fig. 1. Caseolytic activities obtained with crude extracts from various tissues of germinating corn as a function of $\mathrm{pH}$ of the assay medium with and without $10 \mathrm{mM}$ mercaptoethanol. Tissues were harvested $4 \mathrm{~d}$ after sowing. The buffers used were $0.1 \mathrm{M}$ citrate (below $\mathrm{pH} 3.5$ ), $0.1 \mathrm{M}$ acetate $(\mathrm{pH} 4.0$ to 5.5$)$ and $0.1 \mathrm{M}$ phosphate ( $\mathrm{pH} 6.0$ to 8.0). Activities are expressed as $\mu \mathrm{mol}$ free amino groups produced $h^{-1} g^{-1}$ fresh weight. $0 \ldots . .0$ with $M E$, $\bullet-$ without ME 
Table 2. Effect of phenylmethylsulfonylfluoride (PMSF), $p$-hydroxymercuribenzoate (PHMB) and N-ethylmaleimide (NEM) on the activities of endo- and exopeptidases of crude extracts prepared from various tissues of 8-d-old corn seedlings.

Aliquots of crude extract, after dialysis against $50 \mathrm{mM}$ acetate buffer (pH 5.4) for $15 \mathrm{~h}$ at $2^{\circ} \mathrm{C}$, were pretreated, separately, with the three compounds for $24 \mathrm{~h}$ prior to the assay. Mercaptoethanol (ME) when used was added to the assay mixture. NEM and PMSF were initially dissolved in ethanol. Appropriate concentrations of ethanol $(0.2 \%)$ were used in the controls. Because of the marked effect of ME on the endosperm endopeptidases (Fig. 1), assays were made with and without $5 \mathrm{mM} \mathrm{ME}$.

Values are $\%$ of control activity; control activities see below

\begin{tabular}{|c|c|c|c|c|c|c|c|}
\hline \multirow[t]{3}{*}{ Treatment } & \multicolumn{4}{|c|}{ Endosperm } & \multirow{3}{*}{$\begin{array}{l}\text { Scutellum } \\
\text { pH } 5.4 \\
\text { - ME }\end{array}$} & \multirow{3}{*}{$\begin{array}{l}\text { Root } \\
\mathrm{pH} 5.4 \\
-\mathrm{ME}\end{array}$} & \multirow{3}{*}{$\begin{array}{l}\text { Shoot } \\
\text { pH } 5.4 \\
-\mathrm{ME}\end{array}$} \\
\hline & \multicolumn{2}{|l|}{ pH 3.8} & \multicolumn{2}{|l|}{ pH 5.4} & & & \\
\hline & $-\mathrm{ME}$ & $+5 \mathrm{mM} \mathrm{ME}$ & $-\mathrm{ME}$ & $+5 \mathrm{mM} \mathrm{ME}$ & & & \\
\hline \multicolumn{8}{|c|}{ Endopeptidases (casolytic) } \\
\hline Control & $100^{\mathrm{a}}$ & 110 & $100^{\mathrm{b}}$ & 264 & $100^{\mathrm{c}}$ & $100^{\mathrm{d}}$ & $100^{\mathrm{e}}$ \\
\hline PMSF $1 \mathrm{mM}$ & 65 & 76 & 71 & 198 & 79 & 65 & 65 \\
\hline PHMB $1 \mathrm{mM}$ & 21 & 96 & 31 & 273 & 48 & 60 & 73 \\
\hline NEM $2.5 \mathrm{mM}$ & 56 & 95 & 72 & 255 & 92 & 82 & 97 \\
\hline \multicolumn{8}{|c|}{ Aminopeptidase $(p H 7.0)$} \\
\hline Control & & & & $100^{\mathrm{f}}$ & $100^{\mathrm{g}}$ & $100^{\mathrm{h}}$ & $100^{\mathrm{i}}$ \\
\hline PMSF $1 \mathrm{mM}$ & & & & 100 & 101 & 105 & 102 \\
\hline PHMB $1 \mathrm{mM}$ & & & & 14 & 28 & 21 & 13 \\
\hline NEM $2.5 \mathrm{mM}$ & & & & 76 & 95 & 74 & 71 \\
\hline \multicolumn{8}{|c|}{ Carboxypeptidase ( $p H 5.0)$} \\
\hline Control & & & & $100^{\mathrm{k}}$ & $100^{1}$ & $100^{m}$ & $100^{17}$ \\
\hline PMSF $1 \mathrm{mM}$ & & & & 33 & 47 & 18 & 18 \\
\hline PHMB $1 \mathrm{mM}$ & & & & 82 & 88 & 69 & 63 \\
\hline NEM $2.5 \mathrm{mM}$ & & & & 99 & 100 & 96 & 92 \\
\hline ME $2 \mathrm{mM}$ & & & & 112 & - & - & - \\
\hline
\end{tabular}

Control activities were: ${ }^{\mathrm{a}} 14.4 ;{ }^{\mathrm{b}} 7.6 ;{ }^{\mathrm{c}} 9.7 ;{ }^{\mathrm{d}} 11.3 ;{ }^{\mathrm{c}} 1.5$ ( $\mathrm{mmol} \alpha-\mathrm{NH}_{2} \mathrm{~h}^{-1} \mathrm{~g}^{-1}$ fr. wt.); ${ }^{\mathrm{f}} 16 ;{ }^{\mathrm{z}} 131 ;{ }^{\mathrm{b}} 52 ;{ }^{\mathrm{i}} 53\left(\Delta \mathrm{OD}_{410} \mathrm{~h}^{-1} \mathrm{~g}^{-1}\right.$ fr. wt); ${ }^{\mathrm{k}} 42 ;{ }^{1} 83 ;{ }^{\mathrm{m}} 42 ;{ }^{\mathrm{n}} 21$ ( $\mu \mathrm{mol} x-\mathrm{NH}_{2} \mathrm{~h}^{-1} \mathrm{~g}^{-1}$ fr. wt.)

tissue were assayed at $\mathrm{pH} 5.4$ and 7.5 while an additional pH 3.8 assay was run only with endosperm tissue.

Addition of $10 \mathrm{mM}$ ME to the assay medium increased endopeptidase activity in endosperm extracts several-fold $(260 \%$ of the control at $\mathrm{pH} 4.0$ and $325 \%$ at $\mathrm{pH} 5.5$; Fig. 1). In contrast, the enhancement of endopeptidase activity by $\mathrm{ME}$ in extracts from scutella and roots was only maximally $130 \%$ of the controls, and was negligible in extracts from shoots. Addition of ME to extracts from mature or senescing leaves of field-grown corn does not enhance CA-7.5 or CP activity (Feller et al., 1977, and unpublished data), and while it enhances CA-5.4 activity from mature leaves, it does not stimulate this activity from senescing leaves.

\section{Inhibitors and Activators}

Addition of phenylmethylsulfonylfluoride caused a marked reduction in CP activity in extracts from all organs (Table 2). This is consistent with the report of Preston and Kruger (1976) that CP is a serine peptidase. Phenylmethylsulfonylfluoride also caused some loss (average of $30 \%$ ) of endopeptidase activity
(Table 2). However, it cannot be concluded that these are serine-type endopeptidases because with crude extracts, CP may be operating in conjunction with the endopeptidases (Baumgartner and Chrispeels, 1977). AP activity was not affected by phenylmethylsulfonylfluoride.

Addition of $1 \mathrm{mM}$ p-hydroxymercuribenzoate caused a marked reduction in endopeptidase activity from the endosperm and in AP activity from all parts of the seedling but was less effective on the other enzyme activities tested (Table 2). N-ethylmaleimide at $2.5 \mathrm{mM}$ gave partial inhibition of endosperm endopeptidases and of AP's from all parts except the scutellum. Addition of $\mathrm{ME}$ reversed the inhibitory effects of $p$-hydroxymercuribenzoate and $\mathrm{N}$-ethylmaleimide where tested. Other data (not presented) showed that at $0.1 \mathrm{mM} p$-hydroxymercuribenzoate did not inhibit AP and CP extracted from the endosperm.

The addition of $5 \mathrm{mM}$ ME caused only a slight increase in CA-3.8 activity of extracts prepared from endosperms excised from 8-d-old corn seedlings (Table 2). Other experiments (not presented) showed that the addition of $10 \mathrm{mM} \mathrm{ME}$ also failed to stimulate the pH-3.8 endopeptidase activity of extracts from 

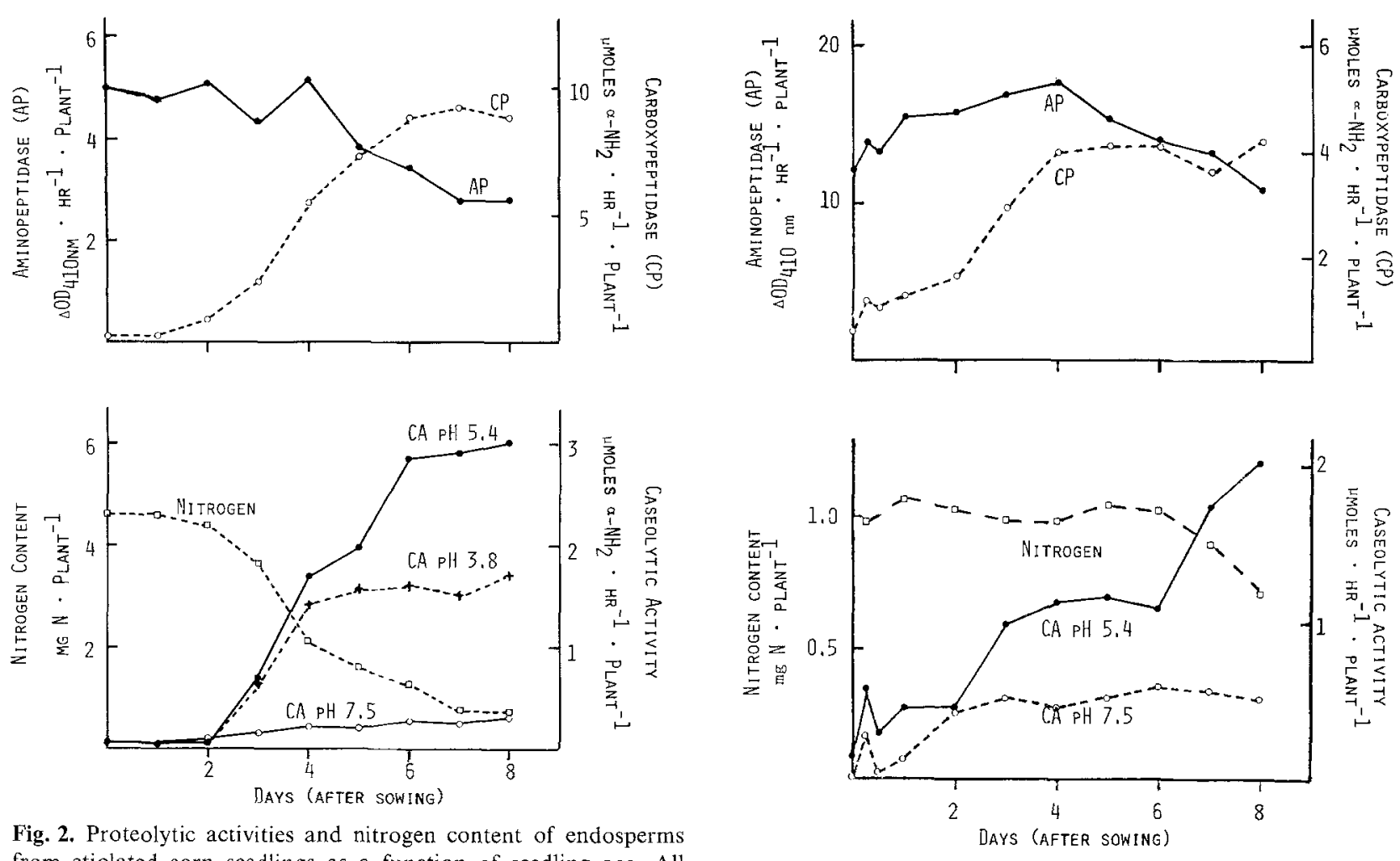

Fig. 2. Proteolytic activities and nitrogen content of endosperms from etiolated corn seedlings as a function of seedling age. All activities are expressed on a per-plant-part basis. Assays were as described in Material and Methods except caseolytic activity at $\mathrm{pH} 7.5$ was assayed at $37^{\circ} \mathrm{C}$ and the amount of substrate, N-carbobenzoxy-L-phenylalanine-L-alanine, increased to $4 \mathrm{mM}$ for the carboxypeptidase assay. The codes are: aminopeptidase, AP; carboxypeptidase, CP; and caseolytic activities at pH 3.8, 5.4 and 7.5, CA-pH 3.8, CA-pH 5.4, and CA-pH 7.5, respectively

endosperms of 4-d-old seedlings. These results are in contrast to the marked increase of $\mathrm{pH}-3.8$ activity when ME was added to extracts from endosperms of 4- or 5-d-old corn seedlings (Fujimaki et al., 1977).

\section{Changes in Proteolytic Activities During Germination}

Endosperm. Changes in proteolytic activities in extracts prepared from endosperms excised from etiolated corn seedlings at intervals over an 8 -d period are shown in Figure 2. $\mathrm{CP}$ and $\mathrm{pH} 3.8,5.4$ and 7.5 caseolytic endopeptidases were barely detectable in the dry endosperms of ungerminated kernels. Starting at day $1, \mathrm{CP}$ activity increased rapidly, reached a maximum by day 6 , and then remained constant. CA's at $\mathrm{pH} 3.8$ and 5.4 increased rapidly from day 2 on and reached a plateau by day 4 and day 6 , respectively. Although the $\mathrm{CA}$ at $\mathrm{pH} 7.5$ was very low it increased progressively throughout the 8 -d period.

The negative relationship between the increases in activity of $\mathrm{CP}$ and the CA's at pH 3.8, 5.4 and 7.5 , and the decreases in endosperm nitrogen (Fig. 2)

indicates but does not prove that these enzymes are responsible for initiating rapid protein mobilization.

AP activity was found in the dry endosperm in substantial amounts. It remained high (or increased slightly in other experiments) during the first $4 \mathrm{~d}$ of seedling growth, and then decreased. The lack of correspondence in the patterns of AP activity and of protein loss (Fig. 2) indicates that this enzyme has only a minor or secondary role in protein mobilization.

Scutellum. Changes in proteolytic activities in extracts prepared from scutella excised from corn seedlings at intervals during an 8-d period are shown in Figure 3. CP and caseolytic activities at pH 5.4 and 7.5 were detectable in the dry scutella; however, they were extremely low in comparison to the AP activity which was very high (2 times) higher than in endosperm on a per-organ basis). During germination, $\mathrm{CP}$ and CA-5.4 increased rapidly during the first $4 \mathrm{~d}$. While CP activity did not change from day 4 through day $8, \mathrm{CA}-5.4$ nearly doubled from day 6 to day 8 . This increase in CA-5.4 was concurrent with the decrease in $\mathrm{N}$ content. The CA-7.5 pattern was similar 
Table 3. Proteolytic activities and nitrogen content in different parts of etiolated corn seedlings during germination Activities were expressed on a per-g-fr.-wt. basis because these tissues were growing in contrast to the endosperm and scutella; however, the weight data permit comparisons. Endosperm and scutella data were taken from Figures 1 and 2, respectively. All values are the averages of two analyses.

\begin{tabular}{|c|c|c|c|c|c|c|c|}
\hline \multirow{3}{*}{$\begin{array}{l}\text { Tissue } \\
\text { and age } \\
\text { (d) }\end{array}$} & \multirow{3}{*}{$\begin{array}{l}\text { Fr. wt. } \\
\text { per plant } \\
(\mathrm{mg})\end{array}$} & \multirow{3}{*}{$\begin{array}{l}\text { Dr. wt. } \\
\text { per plant } \\
\text { (mg) }\end{array}$} & \multirow{3}{*}{$\begin{array}{l}\text { Nitrogen } \\
\text { (mg/g dr. wt.) }\end{array}$} & \multicolumn{4}{|c|}{ Enzyme activities per $\mathrm{g}$ fr. wt. } \\
\hline & & & & \multirow{2}{*}{$\begin{array}{l}\text { Amino- } \\
\text { peptidase } \\
\left(\Delta \mathrm{OD}_{410} \mathrm{~h}^{-\mathbf{1}}\right)\end{array}$} & \multirow{2}{*}{$\begin{array}{l}\text { Carboxy- } \\
\text { peptidase } \\
\left(\mu \mathrm{mol} \mathrm{h} \mathrm{h}^{-1}\right)\end{array}$} & \multicolumn{2}{|c|}{ Caseolytic activity $\left(\mu \mathrm{mol} \mathrm{h} \mathrm{h}^{-1}\right)$} \\
\hline & & & & & & pH 5.4 & $\mathrm{pH} 7.5$ \\
\hline \multicolumn{8}{|l|}{ Root } \\
\hline 3 & 72 & 9 & 6.8 & 22.4 & 7.1 & 5.8 & 3.1 \\
\hline 4 & 145 & 15 & 6.1 & 20.8 & 7.2 & 7.2 & 4.3 \\
\hline 5 & 192 & 21 & 5.6 & 21.4 & 8.5 & 6.0 & 6.8 \\
\hline 6 & 265 & 26 & 4.8 & 16.6 & 7.6 & 6.7 & 6.7 \\
\hline 7 & 230 & 26 & 4.3 & 16.5 & 9.0 & 7.8 & 8.7 \\
\hline 8 & 426 & 35 & 4.0 & 11.7 & 7.7 & 5.7 & 7.8 \\
\hline \multicolumn{8}{|l|}{ Shoot } \\
\hline 3 & 74 & 8 & 8.7 & 48.4 & 4.2 & 0.8 & 0.0 \\
\hline 4 & 230 & 18 & 7.2 & 33.4 & 3.0 & 0.3 & 1.0 \\
\hline 5 & 350 & 27 & 8.8 & 37.1 & 5.0 & 1.7 & 0.7 \\
\hline 6 & 452 & 38 & 7.9 & 31.9 & 6.5 & 2.0 & 1.5 \\
\hline 7 & 538 & 47 & 6.5 & 32.7 & 8.6 & 1.6 & 2.0 \\
\hline 8 & 712 & 62 & 7.0 & 31.2 & 9.5 & 1.3 & 0.9 \\
\hline \multicolumn{8}{|c|}{ Scutellum } \\
\hline 5 & 66 & 20 & 5.3 & 233.3 & 62.1 & 17.6 & 7.9 \\
\hline \multicolumn{8}{|c|}{ Endosperm } \\
\hline 5 & 278 & 138 & 1.3 & 15.4 & 11.6 & 25.2 & 3.2 \\
\hline
\end{tabular}

to the CP-activity pattern (Fig. 3) but on a reduced scale.

AP activity increased during early seedling growth ( $40 \%$ over the ungerminated sample), reached a maximum by day 4 , and then decreased slowly. The lack of correspondence in AP and N patterns (Fig. 3) again indicates at best a secondary role for this enzyme in protein mobilization.

The $\mathrm{N}$ content of the scutella ( $1 / 5$ that of the endosperm) showed only minor changes during the first $6 \mathrm{~d}$ and decreased $(20 \%)$ from day 6 to day 8 . The $\mathrm{N}$ content provides however no measure of protein turnover in this tissue. The protein turnover in the scutella must be high because of the high metabolic activity and physiological functions of this organ (excretion of enzymes, transport of nitrogenous compounds and of sugars to the embryo). The loss of $\mathrm{N}$ from day 6 to day 8 indicates that the scutellum begins to undergo senescence after the reserve protein in the endosperm has been depleted.

Roots and Shoots. The changes in fresh and dry weights (per plant), in the activities of the four proteolytic enzymes, and in $\mathrm{N}$ concentrations during seedling growth are shown in Table 3 . On a dry-weight basis, root growth was essentially linear while shoot growth was sigmoidal over the 3 -to-8-d period.
In the roots the AP activity (fresh-weight basis) decreased $(50 \%)$ over the $5-\mathrm{d}$ period. In contrast, the $\mathrm{CP}$ activity and CA-5.4 remained relatively constant and CA-7.5 increased (over 2-fold). The whole root system, consisting of the primary root and secondary roots and obviously including both newlyformed and senescing tissue, was assayed.

In the shoot the AP activity (fresh-weight basis) decreased $(30 \%)$ between day 3 and day 4 , and remained relatively constant thereafter. The $\mathrm{CP}$ activity increased (2-fold) during the first $5 \mathrm{~d}$. The CA's (pH 5.4 and 7.5) were low and variable, and no definite trend was evident over the 3-to-8-d period.

The root system of corn seedlings (including the primary and seminal roots) had higher levels of CA (several-fold) and lower AP activities (50\%) than the whole shoot. Whereas initially the $\mathrm{CP}$ activity was higher in the root system than in the shoot, the reverse was true at the end of the 8-d growth period.

\section{Proteolytic Activities as a Function of Root Length}

The AP activity of the primary root of 8-d-old seedlings, determined in segments of $1 \mathrm{~cm}$ length, was highest in the apical centimeter, decreased to about $25 \%$ of the tip segment in the next $5 \mathrm{~cm}$, and then increased again, to ca. $50 \%$ of the activity in the tip 

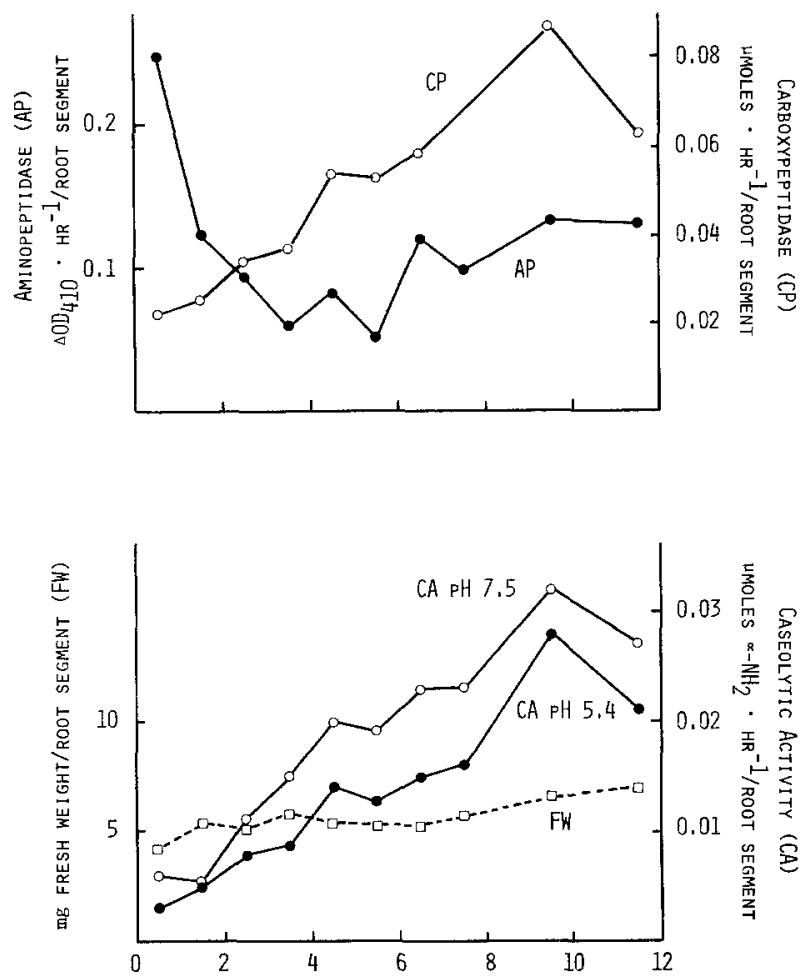

Fig. 4. Proteolytic activities and fresh weight of successive $1-\mathrm{cm}$ segments of primary roots from 8-d-old corn (hybrid LG-11) seedlings. Each sample contained 50 segments and activities are expressed on a per-segment basis

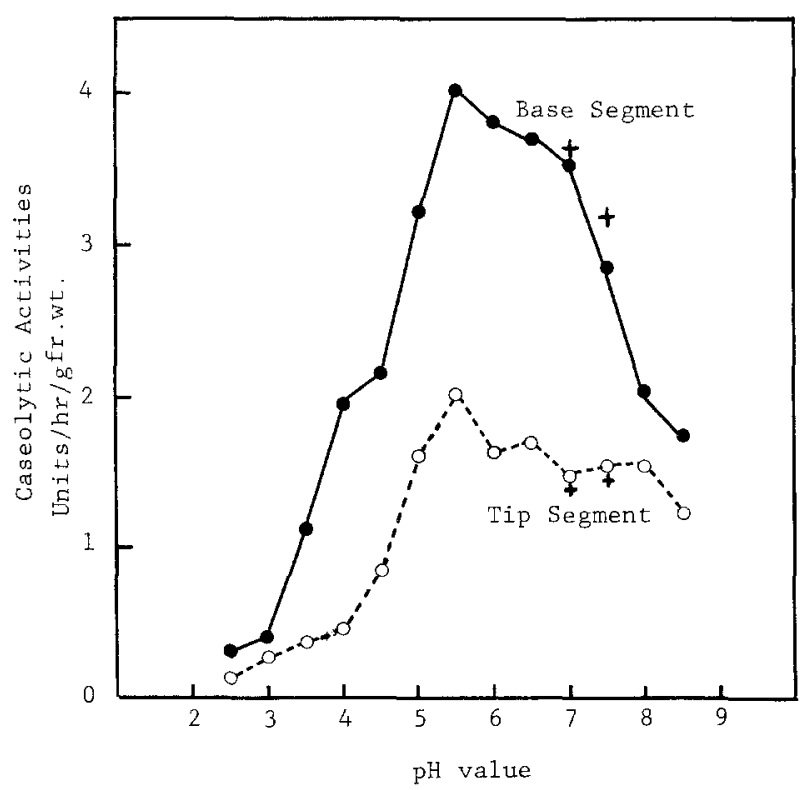

Fig. 5. Caseolytic activities of tip and base segments of the primary root of 6-d-old corn seedlings as a function of the $\mathrm{pH}$ of the assay medium. 2-cm segments were taken from tip and base of 150 individual roots. The crude extracts were dialyzed against

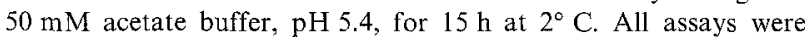
made at $42^{\circ} \mathrm{C}$. The buffers used were: $0.1 \mathrm{M}$ citrate- $\mathrm{KOH}$ (below $\mathrm{pH} 4.0) ; 0.1 \mathrm{M}$ acetate-KOH (pH 4.0-5.5); $0.1 \mathrm{M}$ phosphate $(\mathrm{pH} 6-7.5) ; 0.1 \mathrm{M}$ Tris- $\mathrm{HCl}(\mathrm{pH} 8.0-8.5)$. The + symbol indicates values obtained with Tris at $\mathrm{pH} 7.0$ and 7.5 segment (Fig. 4). Although the weight of the segments increases from tip to base, the increased activity in the basal segments may be attributed to the presence of increased amounts of newly-formed side roots. In contrast, $\mathrm{CP}$ activity was lowest in the root tips and increased in each successive segment from tip to base, with the exception of the most basal segment. The CP activity of the root system per unit fresh weight was relatively constant throughout the experimental period, i.e. did not change with plant age.

CA's at $\mathrm{pH} 5.4$ and 7.5 were low in the tip segment and increased progressively from the tip to the base of the primary root, with the exception of the last basal segment. CA's (fresh-weight basis) at both $\mathrm{pH} 5.4$ and 7.5 were higher in the base than the tip segments of primary roots of 6-d-old seedlings (Fig. 5). In contrast to the data of Figure 4, CA's were higher at $\mathrm{pH} 5.4$ than at 7.5. However, the assay temperature for CA -7.5 was $45^{\circ} \mathrm{C}$ in the experiment of Figure 4 and $37^{\circ} \mathrm{C}$ in that of Figure 5, and this could account for the reversal in the activity levels. The data of Figure 5 also show that the caseolytic enzymes extractable from corn roots are most active in the $\mathrm{pH}$ range of 4.0-8.0.

\section{Discussion}

In senescing leaves of field-grown corn, increases in caseolytic activities at $\mathrm{pH} 5.4$ and 7.5 were concurrent with decreases in leaf $\mathrm{N}$ (Feller et al., 1977). The coincidence of these events indicated a major role for these two enzymes in the rapid hydrolysis of leaf protein.

In endosperms from germinating corn caryopses, increases in CA's at pH 3.8, 5.4 and 7.5 were coincident with the loss of endosperm N. However, when the relative amounts of the activities measured are, taken into account, only the two acidic, sulfhydryldependent endopeptidases appear to play a major role in the hydrolysis of endosperm protein. The importance of the $\mathrm{pH} 3.8$ enzyme in hydrolyzing endosperm protein has been reported by Harvey and Oaks (1974a, b) and Abe et al. (1977). Abe et al. (1977) also identified a second endopeptidase in endosperm tissue but did not characterize it. The CA-5.4 activity pattern (Fig. 2) indicates that this enzyme could play a major role in endosperm protein hydrolysis. Our data, obtained with crude extracts, may overestimate the CA at pH 5.4 because of the possible synergistic effects of endopeptidase and carboxypeptidase on protein hydrolysis (Baumgartner and Chrispeels, 1977). However, the presence of a second enzyme of major importance is supported by the marked increase in CA-5.4 with addition of ME as ME has little effect on CP activity. 
In the scutella of geminating corn kernels, the CA's at pH 5.4 and 7.5 increased during the first $3 \mathrm{~d}$ of seedling growth, but a second increase in activity, concurrent with the loss $(30 \%)$ of scutellar $\mathrm{N}$ (from day 6 to day 8 ), was noted only with CA-5.4 (Fig. 3). Because CA-7.5 was relatively low and changes in its activity patterns did not correspond with loss of $\mathrm{N}$, it cannot be accorded a major role in the mobilization of scutellar $N$ at this stage $(8 \mathrm{~d}$ of seedling development in the dark) of senescence of this tissue.

In extracts from shoots of etiolated corn seedlings, CA's (pH 5.4 and 7.5) were low as would be expected in developing organs that were accumulating protein (on a per-part basis). In the developing root, CA's at $\mathrm{pH} 5.4$ and 7.5 were from 2- to 4-fold higher than in the developing shoot. Whether these higher levels of activities, especially CA-7.5, can be attributed to the fact that the primary root of corn in short-lived and that some of the root hairs are continually senescing is not known. The view that some of the root tissue is senescing and $\mathrm{N}$ is being remobilized to support root extension is supported by data (Table 3) showing that the whole-root system accumulates little $\mathrm{N}$ (calculated on a per-part basis) after day 6 . This implies that both CA-5.4 and CA-7.5 may be involved in hydrolyzing protein in senescing root tissue, as they do in senescing leaves (Feller et al., 1977).

$\mathrm{CP}$ activity was low in young plant parts, increased as the parts developed, and reached relatively high levels in mature and metabolically active plant parts. Decreased CP activity was concurrent with loss of $\mathrm{N}$ from senescing leaves of field-grown corn (Feller et al., 1977) but not with $\mathrm{N}$ loss from endosperms or scutella of corn seedlings. Because the combination of $\mathrm{CP}$ and endopeptidase in vitro synergistically increases the production of $\alpha$-amino groups (Baumgartner and Chrispeels, 1977), CP could increase the rate of hydrolysis of reserve protein for transports to other parts of the seedling.

Of the proteases examined, AP activity was uniquely high in extracts from scutellum and endosperm from dry kernels. The AP activity was also high in plant parts with high metabolic activity (mature leaf, root tip). The concurrent decrease in AP activity with loss of $\mathrm{N}$ from endosperm, scutellum and senescing leaves indicates that this enzyme does not play a major role in mobilization of $\mathrm{N}$ for embryo growth or grain production. The patterns of AP activity in growing tissue were similar to those found by Mikola and Kolehmainen (1972) in germinating barley.

The high activities of exopeptidases and low activities of endopeptidases found in the shoots of seedlings and in mature but photosynthetically active (in contrast to senescing) leaves indicate that this combi- nation of enzymes may be involved in protein turnover in these organs.

This work was supported by a Herman Frasch Foundation grant and by Hatch funds.

\section{References}

Abe, M., Arai, S., Fujimaki, M.: Purification and characterization of a protease occurring in endosperm of germinating corn. Agric. Biol. Chem. 41, 893-899 (1977)

Basha, S.M.M., Beevers, L.: The development of proteolytic activity and protein degradation during the germination of Pisum sativum L. Planta 124, 77-87 (1975)

Baumgartner, B., Chrispeels, M.G.: Purification and characterization of vicilin-peptohydrolase, the major endopeptidase in the cotyledons of mung bean seedlings. Eur. J. Biochem. 77, 223-233 (1977)

Burger, W.C., Siegelman, H.W.: Location of a protease and its inhibition in the barley kernel. Physiol. Plant. 19, 1089-1093 (1966)

Chrispeels, M.J., Boulter, D.: Control of storage protein metabolism in the cotyledons of germinating mung beans: role of endopeptidase. Plant Physiol. 55, 1031-1037 (1975)

Feller, U.K., Soong, T.-S.T., Hageman, R.H.: Proteolytic activities and leaf senescence during grain development of field grown corn (Zea mays L.). Plant Physiol. 59, 290-294 (1977)

Fujimaki, M., Abe, M., Arai, S. : Degradation of zein during germination of corn. Agric. Biol. Chem. 41, 887-891 (1977)

Harvey, B.M.R., Oaks, A.: Characteristics of an acid protease from maize endosperm. Plant Physiol. 53, 449-452 (1974a)

Harvey, B.M.R., Oaks, A.: The hydrolysis of endosperm protein in Zea mays. Plant Physiol. 53, 453-457 (1974b)

Higgins, C.F., Payne, J.W.: Characterization of active dipeptide transport by germinating barley embryos: effects of $\mathrm{pH}$ and metabolic inhibitors. Planta 136, 71-76 (1977)

Jacobsen, J.V., Varner, J.E.: Gibberellic acid-induced synthesis of protease by isolated aleurone layers of barley. Plant Physiol. 42, 1596-1600 (1967)

Melville, J.C., Scandalios, J.G.: Maize endopeptidase: Genetic control, chemical characterization and relationship to an endogenous trypsin inhibitor. Biochem. Genet. 7, 15-31 (1972)

Mikola, J., Kolehmainen, L.: Localization and activity of various peptidase in germinating barley. Planta 104, 167-177 (1972)

Preston, K.R., Kruger, J.E.: Purification and properties of two proteolytic enzymes with carboxypeptidase activity in germinated wheat. Plant Physiol. 58, 516-520 (1976)

Prisco, J.T., Ainouz, I.L., De C. Melo, S.: Changes in nitrogenous compounds and proteases during germination of Vigna sinensis seeds. Physiol. Plant. 33, 18-21 (1975)

Racusen, D., Foote, M.: An endopeptidase of bean leaves. Can. J. Bot. 48, 1017-1021 (1970)

Ryan, C.A.: Proteolytic enzymes and their inhibitors in plants. Ann. Rev. Plant Physiol. 24, 173-196 (1973)

Sopanen, T., Mikola, J.: Purification and partial characterization of barley leucine aminopeptidase. Plant Physiol. 55, 809-814 (1975)

Sundblom, N.-O., Mikola, J.: On the nature of proteinases secreted by the aleurone layer of barley grain. Physiol. Plant. 27, 281-284 (1972)

Visuri, K., Mikola, J., Enari, T.-M.: Isolation and partial characterization of a carboxypeptidase from barley. Eur. J. Biochem. 7, 193-199 (1969)

Received 25 July 1977; accepted 11 January 1978 